Volume 11 Number 4, October-December 2017: pp. 381-397. Copyright (c) 2017 FIAT JUSTISIA. Faculty of Law, Lampung University, Bandarlampung, Lampung, Indonesia. ISSN: 1978-5186 | e-ISSN: 2477-6238.

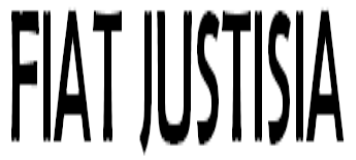

Fiat Justisia is licensed under a Creative Commons Attribution 4.0 International License, which permits unrestricted use, distribution, and reproduction in any medium, provided the original work is properly cited.

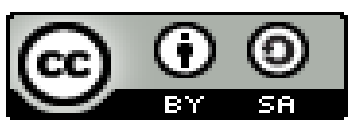

\title{
Legal Implications of the Establishment of Alternative Institution of Dispute Resolution of Indonesian Banking (LAPSPI) on Sharia Banking Dispute Settlement in Indonesia
}

\author{
Nun Harrieti \\ Faculty of Law, The University of Padjadjaran \\ nun_harrieti@yahoo.com
}

\begin{abstract}
Sharia banking is specifically regulated by Law No. 21 on 2008 of Sharia Banking, the provision of Article 55 of the law provides that the resolution of sharia banking disputes shall be conducted by the courts within the scope of religious courts, but does not rule out the existence of other forum authority as agreed by the parties. At the end of 2015, an Alternative Institution of Dispute Resolution of Indonesian Banking (LAPSPI) has been established and registered as a follow-up to the Financial Services Authority Regulation no. 1 / POJK, 07/2014 About the Alternative Dispute Resolution Institution in the Financial Services Sector. It is interesting to be reviewed what the legal implication of LAPSPI's establishment on dispute resolution of sharia banking in Indonesia is. This research was conducted by applying normative juridical approach method with analytical description research specification. Legal implications of LAPSI's establishment are requiring sharia banks to make LAPSPI as the only space and organization recognized in sharia banking external dispute resolution based on LAPSPI article of the association.
\end{abstract}

Keywords: Dispute Settlement, LAPSPI, Sharia Banking. 


\section{A. Introduction}

Financial system provides services which are much needed in the system of modern economics. ${ }^{1}$ Since the enactment of Law no. 7 of 1992 on Banking, the banking system in Indonesia performed the dual banking system, namely the execution of two banking's systems based on the conventional economic principles and based on the sharia economic principles. Sharia economics is an economic system derived from transcendental revelation (al-Quran and as-Sunnah/al-Hadits) and the source of interpretation of the revelation called ijtihad. ${ }^{2}$ Article 6 Sub-Article $m$ of the law provides that one of the banking business activities is to provide financing for customers based on the principle of profit sharing by the provisions stipulated in a Government Regulation. The financing based on the profit-sharing principle in the provision is intended to fund the activities based on sharia principles but is not explicitly mentioned. Furthermore, Article 6 Sub-Article m of Law no. 10 of 1998 on the Amendment to Law No. 7 on 1992 of Banking mentioned that one of banking business activities is to provide financing and or to perform other activities based on sharia principles, by the provisions stipulated by Bank Indonesia. Only then is explicitly mentioned that one of the banking business activities is a business activity based on sharia principles.

These activities are conducted through the establishment of a branch office or an office under a new branch office, but also by changing the branch office or office under the branch office which conducts the conventional business activities into the offices conducting activities based on Sharia Principles. The main provisions stipulated by Bank Indonesia are among others concerning business activities and bank products based on Sharia Principles, establishment and task of the Sharia Supervisory Board, the requirements for the opening of a Branch Office conducting conventional business activities to conduct business activities based on Sharia Principles. Sharia principles embraced by sharia financial institutions based on the values of justice, benefit, balance, and university (rahmatan lil'alamin). ${ }^{3}$

Sharia banking in Indonesia is specifically regulated in Law no. 21 of 2008 concerning Sharia Banking (from now on written the Sharia Banking Law). One of the considerations of the formation of this law is that sharia banking has a specificity compared to the conventional banking, in addition to the arrangements regarding sharia banking in the Banking Law was not specific, so it needs to be specifically regulated in a separate law. The dual banking system in Indonesia is run by double windows system, where conventional banking and sharia banking are run with separate management

\footnotetext{
${ }^{1}$ Ahmad Rodoni, Lembaga Keuangan Syariah, Jakarta: Zikrul Media Intelektual, (2008), p. 6

${ }^{2}$ Mardani, Hukum Ekonomi Syariah di Indonesia, Bandung: Refika Aditama, (2011), p. 1

${ }^{3}$ Andri Soemitra, Bank dan Lembaga Keuangan Syariah, Jakarta: Kencana, (2010), p. 36
} 
and building. Another case with Malaysia, where conventional banking and sharia banking is run with the same management and building or also called a single window system. The initial stage of the development of Sharia banking in Malaysia began with the issuance of the Sharia banking Act in $1983 .{ }^{4}$

Sharia banking is anything that concerns the Sharia Bank and Sharia Business Unit, including institutional, business activities, and ways and processes in conducting its business activities. Sharia banks consist of Sharia Commercial Bank and Sharia People Financing Bank, the difference between the two lies in the provision of services in the payment traffic. Sharia Commercial Banks provide services in the payment traffic, whereas the Sharia People Financing Bank does not provide services in the payment traffic. Sharia Business Unit is a working unit of Conventional Commercial Bank headquarters that serves as the head office of an office or unit conducting business based on sharia principles, or a work unit in a branch office of a bank domiciled abroad conducting conventional business activities that has the function as the headquarter of a sharia sub-branch office and/or sharia unit.

Sharia banking as an intermediary institution is a financial institution that relies heavily on public trust. Therefore, the customer dissatisfaction with sharia banking services must be resolved so as not cause a dispute. However, in practice, many of the customer dissatisfaction led to the emergence of the dispute. To prevent the occurrence of reputation risk, a fast and effective sharia banking dispute resolution mechanism is needed. Article 55 of the Sharia Banking Law provides that the courts shall conduct the resolution of sharia banking disputes within the scope of religious courts, but it does not preclude the authority of other forums as long as agreed by the parties in the contract and not contrary to the principles of sharia.

As of December 31, 2013, the functions, duties, and authority of regulating and overseeing financial services activities in the banking sector shifted from Bank Indonesia (BI) to the Financial Services Authority (OJK). This is as provided in Article 55 paragraph (2) of Law No. 21 on 2011 of Financial Services Authority (from now on written OJK Act). Article 4 of the OJK Act determines that the purpose of the establishment of OJK is to ensure that all activities within the financial services sector are organized in a regular, fair, transparent, accountable manner and capable of realizing a sustainable and stable financial system that protects the interests of the consumers and the public. Protection of the consumers of financial services became one of the focus of arrangements made by OJK at the beginning of

\footnotetext{
${ }^{4}$ Nurul Hudan, Mohamad Heykal, Lembaga Keuangan Islam:Tinjauan Teoritis dan Praktis, Jakarta: Kencana, (2013), p. 135
} 
its establishment, marked with the enactment of Regulation of the Financial Services Authority No. 1 / POJK.07 / 2013 on Consumer Protection of Financial Services Sector (from now on written POJK on Consumer Protection for Financial Services Sector) on August 6, 2013, as the first POJK enacted after OJK was established. Consumers in the definition of this rule mean the parties who place the funds and/or utilize the services available at the Financial Services Institution such as the Customer on the Banking, Capital Market Capitalist, Insurance Policyholder, and the participant in the Pension Fund, based on the laws and regulations in the financial services sector. Article 32 paragraph 1 POJK on Consumer Protection the Financial Services Sector determines that a financial services business actor shall possess and implement a service and complaints resolution mechanism for the consumer, including for sharia banking.

Based on the aforementioned explanation of the article, the service and the resolution of the complaint referred to in this paragraph shall also be included if after receiving a complaint from the consumer of a dispute, namely differences of opinion between consumers and business actors financial services associated with the implementation of the rights and the obligations of the parties. Article 39 of this rule, stipulates that if the resolution of the complaint does not reach an agreement, then the consumer may settle the dispute outside the court or through the courts. The resolution of disputes outside the court referred to in this article is through an alternative institution of dispute resolution (LAPS).

The provisions concerning LAPS are specifically regulated in the Financial Services Authority Regulation no. 1 / POJK.07 / 2014 About the Alternative Institution of Dispute Resolution (from now on POJK about LAPS). LAPS is an institution conducting non-court dispute resolution established by a financial services agency coordinated by an association and established by an agency that operates a self-regulatory organization function. At the end of 2015, it has been established and registered in the OJK of the Alternative Institution of Dispute Resolution of Indonesia Banking (LAPSPI) as special LAPS for the resolution of disputes between clients and banks outside the court. LAPSPI was formed by six banking associations, namely the National Bank Association (PERBANAS), the State-Owned Bank Association (HIMBARA), the Association of Regional Development Banks (ASBANDA), the Association of Indonesian Sharia Banks (ASBISINDO), the Association of International Banks Indonesia (PERBINA) and the Association of Indonesian Public Credit Bank (PERBARINDO). It is interesting to examine how the legal implication of the formation of LAPSPI towards the resolution of sharia banking disputes in Indonesia? 


\section{B. Methods}

This research uses normative juridical approach method which involves research of positive law inventory, research on law principles and in concreto law research, systematic research of the law, research of legal history and comparison of law. ${ }^{5}$ This research is conducted by examining the data of the library or secondary data obtained from libraries and related institutions that are competent with this research. The specification of this research is analytical descriptive, which is by making a systematic description of the facts including describing the rules that applied. ${ }^{6}$ Thus, this study will illustrate various legal issues obtained through the inventory of positive law, the discovery of legal principles and the discovery of in concerto law on the mechanism of dispute resolution of sharia banking which aims to obtain a comprehensive and systematic picture through an analytical process using legal rules, legal principles and legal understanding of the resolution of sharia banking disputes.

\section{Result and Discussion}

\section{Legal Implications of LAPSPI's Establishment of the Resolution of Sharia Bank Disputes in Indonesia}

Article 1 point 13 POJK concerning LAPS provides a definition of dispute that is a conflict between consumer and financial service institution in fund placement activity by the consumer at financial service institution and service utilization and product of financial service institution after going through a complaint resolution process by financial service institution. Customers are the consumers of financial services institutions specialized in banking. There are three types of customers in sharia banking that are depositors, investor and facility recipient customers. The legal relationship between sharia banking and the three types of customers can be illustrated in the chart below:

\footnotetext{
${ }^{5}$ Ronny Hanitijo Soemitro, Metodelogi Penelitian Hukum dan Jurimetri, Jakarta: Ghalia Indonesia, (1990), pp. 9-10.

${ }^{6}$ Sumadi, Metode Penelitian, Jakarta: Rajawali, (1998), p. 19.
} 


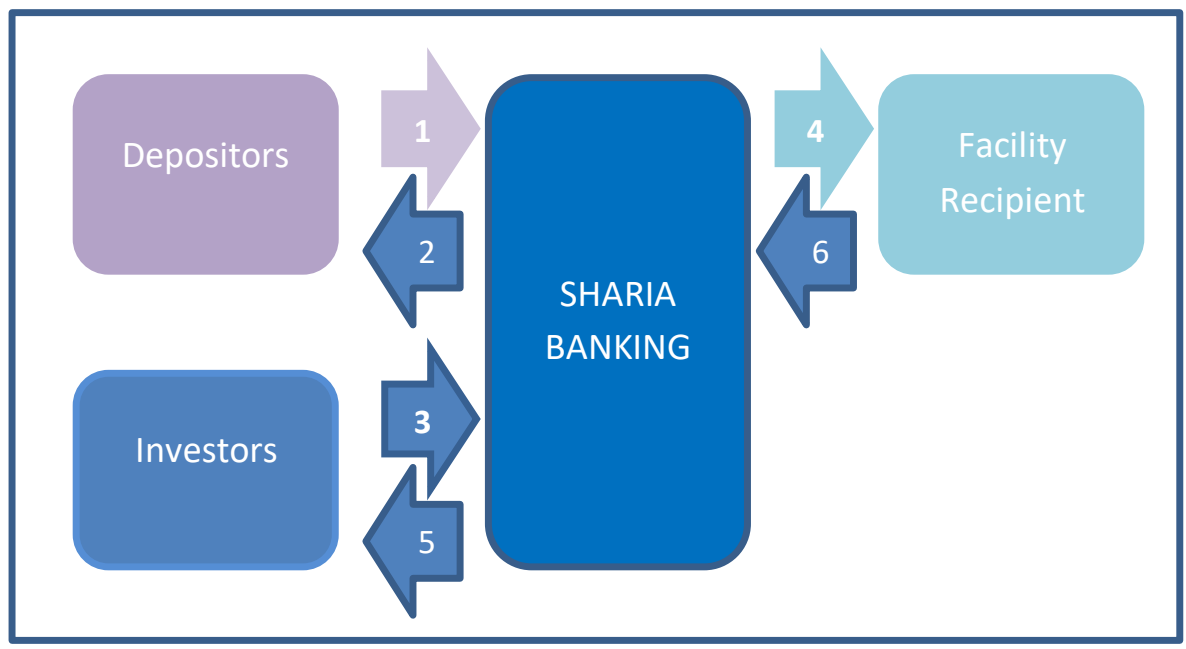

Chart 1. The Intermediary Function of Sharia Banking Explanation:

1. Depositors keep their funds in sharia banking in deposit products

2. Sharia banking hands over the customer deposits

3. Investors place their funds in sharia banking in investment products

4. The sharia banking distributes funds from investor to the facility recipient customer in financing products

5. Facility recipient customer hand over the profit sharing ratio to sharia banking

6. Sharia banking hand over the profit sharing ratios to the investor

Depositors are the customer who places their funds in a Sharia Bank and Sharia Business Unit in the form of deposits based on an agreement between a Sharia Bank or a Sharia Business Unit and the respective customer. Depositors place their funds in sharia banking in deposit products for non-investment purposes, so in principle, there is no profit-sharing ratio received by depositors. Sharia banking delivers depositor funds when the depositors withdraw it, Akad (agreement) commonly used is Al-Wadiah. The investor is a customer who placed his funds in a Sharia Bank and Sharia Business Unit in the form of an investment based on an agreement between the Sharia Bank or the Sharia Business Unit and the respective customer. The investors place their funds in sharia banking with the purpose of investment, akad commonly used is mudaraba, so in principle, the investor receives a loss and profit sharing from sharia banking. Loss and profit sharing is derived from the financing distributed by sharia banks to the recipient facility customers. The Facility Recipient Customer is a customer who obtains a fund or equivalent facility based on sharia principles. So the 
legal relationship between sharia banking and its customers is based on the Akad agreed by both parties. Akad is a written agreement between a Sharia Bank or a Sharia Business Unit and another party which contains the rights and the obligations of each party by the Sharia Principles. Also, there are also walk-in customers; they are the customers who do not have an account at the bank concerned but use the services in the sharia banking.

The dispute arising between customers and sharia banks must be resolved quickly, effectively and efficiently, as sharia banking as an intermediary institution is heavily dependent on public trust, so the risk of reputation should be minimized. Therefore, Sharia Banking is required to have a working unit and a function to handle and resolve complaints filed by consumers, as defined in Article 36 paragraph 1 of the POJK on Consumer Protection of Financial Services. Article 1 Figures 12 POJK About LAPS provides a definition of Complaints namely the delivery of expression of consumer dissatisfaction caused by the loss or potential financial losses to consumers allegedly occurred by mistake or negligence of the Financial Services Institution in the placement of funds by the Consumer at the Financial Services Institution and/or the utilization of services and/or products of the Financial Services Institution. Upon the receipt of a customer complaint, sharia banking is required to conduct an internal, competent, true, and objective internal examination, conduct analysis to confirm complaints, and submit an apology and offer redress/remedy or repair of products and or services, if the customer complaint is correct. If no agreement is reached in the resolution of this complaint, the customer may settle a dispute outside the court or through a court.

Based on the definition of dispute set forth in Article 1 point 13 POJK About LAPS, it can be drawn elements of the dispute referred to this rule, namely disputes, between the consumer and the Financial Services Institution, in the activity of placement of funds or utilization of services of Financial Services Institution products, after through a process of complaint resolution by Financial Services Institution. So that the dispute in sharia banking arises when the process of resolution of customer complaints by sharia banks do not reach an agreement. Resolution of disputes that may arise in sharia banking is done through the courts within the religious court; also, there is also the possibility of dispute resolution based on the agreement of the parties as outlined in the akad. Based on the explanation of Article 55 paragraphs 2 of the Law on Sharia Banking, the meaning of "dispute resolution is done in accordance with the contents of the Akad" are the following efforts: deliberation, banking mediation, through the National Sharia Arbitration Board (Basyarnas) or other arbitration institutions, and/or through the courts within the general judicial environment. But today the way of dispute resolution through the judiciary gets a pretty sharp criticism, 
both from the practitioners and the legal theorists. The role and the function of the judiciary are considered to be overloaded, slow and a waste of time, very expensive and unresponsive to the public interest or considered formalistic and too technical. ${ }^{7}$

Article 2 of POJK regarding LAPS determines that in the event of non-compliance in the resolution of complaints made by the Financial Services Institution, consumers and Financial Services Institutions may settle the dispute outside the court (external dispute resolution) or through the court (internal dispute resolution). The resolution of disputes through the courts is conducted through religious courts, but the parties may also do so through general courts as long as it is agreed upon in the contract. It is as stipulated in Article 55 of the Sharia Banking Law and its explanation. The settlement of disputes outside the court in question is through LAPS which is contained in the LAPS list stipulated by OJK, and the Financial Services Institution is required to become a member of the LAPS. In late 2015, it has formed LAPS in the banking and sharia banking called LAPSPI. The vision of this institution is to be an alternative dispute resolution institution professionally and fairly, reliably and the main choice of customers and banks in resolving the dispute. ${ }^{8}$ The mission is to provide alternative services for dispute settlement that is fair, fast, cheap, and efficient, providing dispute resolution service schemes that are easily accessible by the consumers, providing competent, credible, and integrity of Mediator, Adjudicator, and Arbitrators, implementing good governance in accordance with the principles of transparency, accountability, responsibility, independence, and fairness, encourage the banking industry and the community to use LAPSPI as the main alternative dispute resolution institution. $^{9}$

LAPSPI provides dispute resolution services through an out-of-court dispute resolution mechanism that includes mediation, adjudication, and arbitration. ${ }^{10}$ Resolution of disputes through the court or outside the court, the basic completion determination depends on the parties to the contract (party economy) when the contract was agreed. ${ }^{11}$ There are several requirements for a dispute to be settled through LAPSPI which is a civil dispute arising between the parties in the field or related to the banking,

\footnotetext{
${ }^{7}$ Nevey Varida Ariani, “Alternatif Penyelesaian Sengketa Bisnis Diluar Pengadilan”, Jurnal RechtsVinding, 1 (2), (2012), p.1

${ }^{8} \mathrm{https}$ ://lapspi.org/profile/visi-misi-dan-core-values, accessed on 1 September 2017, at 06.00 WIB

${ }^{9}$ Ibid.

${ }^{10} \mathrm{https}$ ://lapspi.org/profile/lingkup-layanan, accessed on 1 September 2017

${ }^{11}$ Siti Nurbaiti, "Mediasi:Salah satu Alternatif Penyelesaian Sengketa Asuransi di Indonesia", Jurnal Hukum Prioris, 2 (1), (2008), p. 31
} 
there is an agreement between the disputants that the dispute will be settled through LAPSPI, there is a written request (dispute registration) from the parties to LAPSPI, and is not a dispute within the scope of criminal and/or administrative law. Article 6 paragraph 2 LAPSPI's Articles of Association determines that any Financial Services Institution in the banking sector that has a banking business license, automatically become members of the association and will be recorded in the Member List. Membership of LAPSPI until March 15, 2017 amounts to 141 members consisting of all Commercial Banks/Sharia (including Foreign Banks and Joint Venture) of 116 members, and 25 representatives of Rural Banks/Sharia Rural Banks.

Each LAPSPI member shall have the right to attend and to vote in the General Meeting of Members, nominate, elect the Board and the Regulatory Body, submitting opinions or suggestions in the General Meeting of Members, obtaining information, education and training services, obtaining services and equal treatment, obtaining guidance, consultation on mediation, adjudication, and arbitration, present at the time of the Board shall establish the act of discipline or judgment of the conduct of the member concerned, defend their self against a decision/regulation that harms them. While Member Liability is to pay the financial obligations of members who are determined, submissive and obedient to the Articles of Association, bylaws, code of ethics and other established rules, as well as any legitimate decision of the General Meeting of Members or Board Meetings, uphold and maintain the institution's good name, recognizes LAPSPI as the only place and organization in resolving disputes outside the court, supporting the implementation of the institutional programs in order to advance the banking industry, as well as attend meetings and activities for members organized by the institution.

One of the LAPSPI Member obligations embodied in LAPSPI's Articles of Association is to acknowledge LAPSPI as the sole place and organization in resolving non-court disputes, while any Financial Services Institution in the banking sector which has a banking business license, automatically becomes a member of LAPSPI and is recorded in the Member List, so that with the formation of this LAPSPI sharia banking has an obligation to use LAPSPI in settlement of disputes outside the court. Sharia banking membership in LAPSPI ends if the authorized institution revokes the business license of members of the association as a banking financial services institution. Thus, it can be said that LAPSPI's legal implications for the resolution of sharia banking disputes in Indonesia are making LAPSPI as the only place an organization recognized in the resolution of sharia banking disputes out of court.

Dispute resolution services conducted by LAPSPI include mediation, adjudication, and arbitration. Mediation is a way of resolving disputes 
outside the court through a process of negotiation to obtain a peace agreement with the assistance of a mediator. ${ }^{12}$ One of the reasons for choosing mediation is the willingness of the parties to resolve disputes without harming one party (win-win solution), it is hoped that with such a fair solution, the parties can maintain a long-term mutual relationship. The mediator is a neutral party that helps the parties in the negotiation process to seek solutions to dispute resolution, but the mediator is not allowed to break or impose a resolution. ${ }^{13}$ The mediator function only facilitates the meetings within the mediating framework of the disputing parties to understand the perspectives, positions, and interests of each party over the dispute faced and found a dispute resolution alternative fairly, quickly, cheaply and efficiently. The mediator in carrying out his duties is governed by the Code of Conduct to ensure that mediators are impartial and independent. ${ }^{14}$

In this LAPSPI service, mediation may be used at each stage of the dispute settlement, i.e. after the deliberate deliberation fails, during the adjudication process proceeds and the decision has not been reached, when the Arbitrator / Arbitrator Council offers a peace effort at the first hearing before the judge begins the hearing cases and during the arbitration proceedings have not been rendered. There are several criteria that must be met for a dispute to be resolved through LAPSPI mediation: is a civil dispute in the field of Banking or related to banking field, disputes concerning rights which, by law and statutory law, are fully controlled by the Party in dispute, disputes which, according to the laws and regulations may be held peace, disputes which have taken deliberation but parties failed to achieve peace, and between the petitioners and the respondent have been bound by the mediation agreement. ${ }^{15}$

The parties make the mediation agreement after the deliberation of the consensus does not reach an agreement. Mediation agreements may be made before the dispute contained in the dispute resolution clause of the principal agreement between the sharia banking and the customer or may be made after the dispute. The form may be contained in a written document signed by the parties or in the form of a statement of the parties before the LAPSPI arbitration trials. If the agreement is made in the form of revelation, it is sufficient to prove it by the Minutes of the Arbitration Trial of LAPSPI. The mediation agreement contains a statement that the parties are willing to be

\footnotetext{
${ }^{12} \mathrm{https}$ ///lapspi.org/category/pelayanan/mediasi, accessed on 1 September 2017

${ }^{13}$ Ibid.

${ }^{14}$ Ibid.

${ }^{15} \mathrm{https}: / /$ lapspi.org/pelayanan/mediasi/syarat-pendaftaran-dan-verifikasi-mediasi, accessed on 1 September 2017
} 
bound, submissive and execute any agreements that may be reached in LAPSPI mediation, as well as cover the costs required. ${ }^{16}$

Mediation shall be held by request made by the Parties or one of the parties to LAPSPI; a request shall be submitted in writing consisting of a mediation request letter and attachments. The mediation request letter contains the full name and place of residence or place of the parties, a brief description of the dispute, and the content of the claim. The appendices shall consist of a copy of the payment receipt of the registration fee, a copy of the mediation agreement, the deeds of the filed evidence and their statements, photocopies/copies of supporting evidence documents. The LAPSPI Board verifies the registration file of the mediation request, on the result of the verification; the Board submits the confirmation of acceptance or rejection of the registration of the Mediation Application to the Petitioner and the Respondent. ${ }^{17}$ If the request for mediation is rejected by LAPSPI's board, it must include the reasons and the parties may re-submit the request for mediation after meeting the stipulated requirements and time, if the mediation request is received it will be given an acceptance confirmation letter containing notice on the commencement of the appointment of the mediator, notification of the name of the secretary appointed by the Management for the case concerned, as well as the information on the mediation fees of the case concerned. The request for mediation received will be recorded in LAPSPI case register book.

The duties and obligations of the mediator are to foster and facilitate the communication between the parties to the dispute, facilitate the hearing among the parties, assist the parties to understand each other's perspectives, positions and interests in relation to the disputed, ensure that all parties have equal opportunity to be heard so that all parties feel equal, mediators do not make binding decisions but they help the parties to inventory and develop settlement options and choose the best option for the parties, mandatory mediators obey the rules of ethics, the mediator shall be obliged to give equal opportunity to each party to be heard of their statements, opinions, and wishes, and the mediator shall immediately resign if after accepting the appointment as mediator, then realizing that the concerned is not complying with one or more conditions as stipulated in the regulation of LAPSPI. In the view of these tasks, it takes a mediator who has the expertise or experience in the field required. In this LAPSPI mediation, it is possible for the LAPSPI board to appoint Co-mediators. In principle, the appointment of the mediator is based on the agreement of the parties submitted to the mediator through the LAPSPI board, but the management has the authority to designate the

\footnotetext{
${ }^{16} \mathrm{https}: / /$ lapspi.org/pelayanan/mediasi/perjanjian-mediasi, accessed on 1 September 2017

${ }^{17}$ Ibid.
} 
mediator for the interest of the parties if the parties submit the mediator appointment to the board or the parties fails to appoint the mediator within the stipulated time. ${ }^{18}$ In the LAPSPI mediation, no Ad Hoc mediator is identified, but who may be appointed as mediator in LAPSPI Mediation is the person who has been appointed as a permanent mediator of LAPSPI. ${ }^{19}$

The mediation of the negotiations shall last no longer than 30 days and with the agreement of the parties, and the mediator may be renewed within another 30 days. ${ }^{20}$ In the mediation process, two possibilities are successful or fail. Mediation is said to succeed if the mediation process leads to the signing of a peace agreement between the parties. If the parties want the peace agreement to have an executorial power, then the peace agreement can be poured into the Deed of Peace (Acta Van Dading) by the Arbitral Assembly/Single Arbitrator if the mediation is exercised within the framework of the arbitration process. ${ }^{21}$ The peace deed has the legal power of justice as has been a permanent legal ruling. Mediation is said to fail if the negotiations have been deadlocked and the parties will not continue. If this failure occurs, the settlement process shall be re-submitted to each party, whether subsequently will choose the arbitration or court route. If the mediation is held within the framework of the arbitration, then the Arbitral / Arbitrator Assembly resumes the arbitration proceedings. ${ }^{22}$

In general, when properly implemented, mediation will result in solutions by the desired parties. ${ }^{23}$ The weakness of mediation is only when the tasks run by the mediator are not running maximally due to various constraints, resulting in solutions that do not satisfy the parties. Also, the agreement made is a gentle agreement, may be violated or not implemented if there is no good faith from the parties. In addition to mediation, it can also be done through the adjudication. Adjudication is the settlement of disputes outside the arbitration and general courts by the adjudicator to produce an acceptable verdict by the Petitioner, so with the acceptance of such decision shall bind the Respondent party. ${ }^{24}$ An adjudicator is a person appointed under LAPSPI adjudication rules and procedures to examine the case and provide adjudication decisions on a particular dispute submitted to the LAPSPI. ${ }^{25}$

\footnotetext{
${ }^{18} \mathrm{https} / / /$ lapspi.org/pelayanan/mediasi/penunjukan-mediator, accessed on 2 September 2017

${ }^{19}$ Ibid.

${ }^{20} \mathrm{https} / / /$ lapspi.org/pelayanan/mediasi/perundingan-mediasi, accessed on 2 September 2017

${ }^{21} \mathrm{https} / / /$ lapspi.org/pelayanan/mediasi/hasil-mediasi, accessed on 2 September 2017

22 Ibid.

${ }^{23}$ Wirdyaningsih, dkk, Bank dan Asuransi Islam di Indonesia, Jakarta: Kencana Prenada Media, (2006), p. 226

${ }^{24} \mathrm{https}: / /$ lapspi.org/pelayanan/adjudikasi/pendahuluan-adjudikasi, accessed on 2 September 2017

${ }^{25}$ Ibid.
} 
Although the LAPSPI management appoints the adjudicator, the parties retain the right to refuse the appointment if the adjudicator has a conflict of interest. ${ }^{26}$ There are several requirements that must be fulfilled in order for a dispute to be resolved through LAPSPI adjudication which is a dispute in banking and/or related to banking, disputes over rights which, under the law of statutory law, are fully controlled by the parties to the dispute, disputes which, according to the legislation may be peace, disputes that have taken mediation efforts but the parties have failed to achieve peace, and between the applicant and the requested party are bound by an adjudication agreement. ${ }^{27}$ The parties make the adjudication agreement after the dispute resolution efforts through mediation does not reach a peace agreement made by the parties within a maximum period of five days after the confirmation of receipt of LAPSPI is received by the parties. The nature of the adjudication mechanism is the granting of an option for the Applicant to accept or not to accept the adjudication decision. The adjudication decision is final and binding on the parties after the applicant receives and signs the adjudication decree. The adjudication decisions that the applicant has received shall be executed in good faith by the parties and cannot be brought against the resistance or denial. Unlike the LAPSPI arbitration that allows referring persons outside of the LAPSPI Arbitrator Register List as an Arbitrator in a case (ad hoc arbitrator), the LAPSPI adjudication of the Management only refers to the Adjudicator listed in the LAPSPI Permanent Adjudicator List. ${ }^{28}$ The duration of the adjudication check shall be no later than 60 days after the date of the appointment of the adjudicator or the establishment of adjudicator panel and the extension of the examination time of 30 days.

The process of adjudication is confidential and takes place in a closed manner which is attended only by the parties and its attorney, adjudicator/panel adjudicator and secretary unless the parties require another or as necessary for the execution of adjudication decisions as the reason allowed. ${ }^{29}$ The adjudication verdict is final and binding on the parties after the applicant declares to accept and sign the verdict so that it cannot be appealed. If the applicant refuses the adjudication decision, then the verdict is not binding on the parties and is considered never existed. The acceptance

\footnotetext{
${ }^{26} \mathrm{https}: / /$ lapspi.org/pelayanan/adjudikasi/penunjukan-adjudikator, accessed on 2 September 2017

${ }^{27}$ Ibid.

${ }^{28}$ Ibid.

29 https://lapspi.org/pelayanan/adjudikasi/kerahasiaan-adjudikasi, accessed on 2 September 2017
} 
or the rejection of the decision by the applicant shall concern the whole verdict, not only in part. ${ }^{30}$

In addition to mediation and adjudication, the dispute resolution service that can be done through LAPSPI is arbitration. Arbitration is a method of solving civil disputes in the banking field and related to banking outside the general court, organized by LAPSPI using LAPSPI arbitration rules and procedures. ${ }^{31}$ The reasons for choosing arbitration are also due to such things as freedom, trust, and security, skill, quick and cost-effective, confidential, non-precedent, arbitrator sensitivity, execution of decisions and modern trends. ${ }^{32}$ Generally, arbitration, mediation or other means of dispute resolution outside the court may be equivalent to a dispute by persons skilled in the disputed object with relatively fast completion times, mild costs and parties can resolve disputes without publicity that could harm the reputation and so on. ${ }^{33}$

The arbitrator shall be one or more who is a permanent arbitrator of LAPSPI or non-permanent arbitrator of LAPSPI appointed under LAPSPI rules and procedures as Single Arbitrator/Arbitral Tribunal, to examine the case and provide an arbitral award on a particular dispute submitted to the LAPSPI.

In contrast to mediation and adjudication, in the LAPSPI arbitration, it is possible to appoint an arbitrator outside the arbitrator's list established by LAPSPI. The arbitration shall be chosen by the parties to obtain a final and binding decision by right-based procedure/approach. The arbitration route is relatively faster than the litigation path, and the arbitral award can be implemented without any constraints on the jurisdiction of the state. Due to the final and binding arbitral award, no appeal against the arbitration award can be made. The arbitrator can also make decisions by justice and propriety (ex aequo et bono) not solely by legal provisions. One of the requirements for a dispute over sharia banking can be done through arbitration is between the Petitioner and the Respondent is bound by the Arbitration Agreement.

An arbitration agreement may be incorporated into one of the articles of the provision made by the parties before the dispute (the arbitration clause) or made in a separate agreement made by the parties following the dispute. The arbitration shall be held by a written arbitration petition filed by the applicant to LAPSPI by previously giving notice to the Respondent that the arbitration terms as stipulated in the mutually agreed agreement have

\footnotetext{
${ }^{30} \mathrm{https} / / /$ lapspi.org/pelayanan/adjudikasi/putusan-adjudikasi, accessed on 2 September 2017

${ }^{31} \mathrm{https}$ ://lapspi.org/pelayanan/arbitrase/pendahuluan-arbitrase, accessed on 2 September 2017

${ }^{32}$ Sri Retno Widyorini, "Penyelesaian Sengketa Dengan Cara Arbitrase”, Jurnal Hukum dan Dinamika Masyarakat, 4 (1), (2006,), p.1

${ }^{33}$ Rahmadi Indra Tektona, "Arbitrase Sebagai Alternatif Solusi Penyelesaian Sengketa Bisnis di Luar Pengadilan", Pandecta, 6 (1), (2011), p. 90
} 
been applied, so that dispute resolution will soon be submitted to LAPSPI Arbitration. The arbitrator is an individual who due to his competence and integrity is elected by the parties to the dispute to examine and provide a decision on the dispute concerned. The parties have the right to appoint the Arbitrator, and the Arbitrator shall have the right to accept or reject the appointment. ${ }^{34}$ In the LAPSPI arbitration process, the parties must first agree on the form of arbitration to be used, whether in the form of a single arbitration or arbitrary assemblies of at least three arbitrators and an odd number.

The stages of the LAPSPI Arbitration Arrangement begin with the first hearing and the peaceful endeavor, the submission of Replies-ReplicDuplik, submission, and matching of evidence, hear hearings of each party, the submission of written statements of witnesses (facts and experts), hearings of witnesses (fact or expert), submission of additional evidence / witnesses if any, conclusion of each party, trial of decision readings, enforcement of judgments in the district court, execution of decision. The principal examination of the case shall take place at least 180 days from the date of the sole arbitrator designated or the arbitral tribunal is established, the arbitrator shall determine the day of the hearing to pronounce the Arbitral Award within 30 days of the examination.

The arbitral award shall be read in a closed session to the public with or without the presence of the parties to the dispute. In making a decision, a sole arbitrator / arbitral tribunal shall be free from any party's intervention, including LAPSPI's board or the authority of the Indonesian Banking, the arbitrator / arbitral tribunal may decide on the basis of legal provisions or in accordance with the sense of fairness and appropriateness (ex aequo et bono), the LAPSPI arbitration award in an arbitral tribunal shall be decided on the basis of deliberation for the consensus, if not reached, the decision shall be made on the basis of the majority vote by granting the right to inclusion of dissenting opinion. ${ }^{35}$ The arbitral award is final and has the permanent legal force and binds the parties, so there can be no appeal, cassation or review. The role of the court in the execution of the ultimate arbitral award is to be the executor or executive of the arbitral award.

\footnotetext{
${ }^{34} \mathrm{https} / / /$ lapspi.org/pelayanan/arbitrase/penunjukan-arbiter, accessed on 2 September 2017

${ }^{35} \mathrm{https} / / /$ lapspi.org/pelayanan/arbitrase/putusan-arbitrase, accessed on 2 September 2017
} 


\section{Conclusion}

\section{Conclusion}

The legal implications of LAPSPI's establishment of the dispute resolution over sharia banking in Indonesia require sharia banks to make LAPSPI as the only space and organization recognized in sharia banking external dispute resolution based on LAPSPI article of association.

\section{Suggestion}

Sharia banking should include LAPSPI as a means of dispute resolution outside the courts within their contracts with the customers. The resolution of sharia banking disputes should be prioritized beyond the courts through LAPSPI so that the disputes can be resolved by the competent parties in sharia banking in particular and to minimize the occurrence of reputation risk in sharia banking.

\section{A. Books}

\section{Bibliography}

Mardani. (2011). Hukum Ekonomi Syariah di Indonesia. Bandung: Refika Aditama.

Nurul Hudan and Mohamad Heykal. (2013). Lembaga Keuangan Islam:Tinjauan Teoritis dan Praktis. Jakarta: Kencana.

Rodoni, Ahmad. (2008). Lembaga Keuangan Syariah. Jakarta: Zikrul Media Intelektual.

Soemitra, Andri. (2010). Bank dan Lembaga Keuangan Syariah. Jakarta: Kencana.

Soemitro, Ronny Hanitijo. (1990). Metodelogi Penelitian Hukum dan Jurimetri. Jakarta: Ghalia Indonesia.

Sumadi. (1998). Metode Penelitian. Jakarta: Rajawali.

Wirdyaningsih, dkk. (2006). Bank dan Asuransi Islam di Indonesia. Jakarta: Kencana Prenada Media

\section{B. Journal and Article}

Joejoen Tjahjani, "Peranan Pengadilan dalam Pelaksanaan Putusan Arbitrase", Jurnal Independent, 2 (1).

Nevey Varida Ariani, (2012), "Alternatif Penyelesaian Sengketa Bisnis Diluar Pengadilan", Jurnal RechtsVinding, 1 (2).

Rahmadi Indra Tektona, (2011), "Arbitrase Sebagai Alternatif Solusi Penyelesaian Sengketa Bisnis di Luar Pengadilan”, Jurnal Pandecta, 6 (1).

Siti Nurbaiti, (2008), "Mediasi:Salah satu Alternatif Penyelesaian Sengketa Asuransi di Indonesia", Jurnal Hukum Prioris, 2 (1). 
Sri Retno Widyorini, (2006), "Penyelesaian Sengketa Dengan Cara Arbitrase", Jurnal Hukum dan Dinamika Masyarakat, 4 (1).

\section{Legislation}

Republic of Indonesia Law No. 21 on 2008 of the Sharia Banking

Republic of Indonesia Law No. 21 on 2011 of the Financial Services Authority

Republic of Indonesia Law No. 7 ofn1992 of the Banking as amended by Republic of Indonesia Law No. 10 on 1998 of Amendment to Republic of Indonesia Law No. 7 on 1992 of Banking

Regulation of the Financial Services Authority No. 1 / POJK.07 / 2014 on the Alternative Dispute Settlement Institution

Regulation of the Financial Services Authority No. 1/ POJK.07 / 2013 on the Consumer Protection in Financial Services Sector

\section{World Wide Web}

https://lapspi.org/pelayanan/adjudikasi/kerahasiaan-adjudikasi, accessed on 2 September 2017

https://lapspi.org/pelayanan/adjudikasi/pendahuluan-adjudikasi, accessed on 2 September 2017

https://lapspi.org/pelayanan/adjudikasi/putusan-adjudikasi, accessed on 2 September 2017

https://lapspi.org/pelayanan/arbitrase/pendahuluan-arbitrase, accessed on 2 September 2017

https://lapspi.org/pelayanan/arbitrase/putusan-arbitrase, accessed on 2 September 2017

https://lapspi.org/pelayanan/mediasi/hasil-mediasi, accessed on 2 September 2017

https://lapspi.org/profile/lingkup-layanan accessed on 2 September 2017https://lapspi.org/pelayanan/mediasi/perundingan-mediasi, accessed on 2 September 2017

https://lapspi.org/profile/visi-misi-dan-core-values, accessed on 2 September 2017 